\title{
A study of attention and imagery capacities in badminton players
}

\author{
Gulsum BASTUG ${ }^{1}$, Ali AGILONU ${ }^{1}$, Nuri BALKAN ${ }^{2}$ \\ ${ }^{1}$ Mugla Sitkı Kocman University, Faculty of Sports Sciences, Mugla, Turkey. \\ 2 Söke Söktaş 75.Yil Secondary School, Aydin, Turkey. \\ Address correspondence to G. Bastug, e-mail: gbastug@mu.edu.tr
}

\begin{abstract}
The purpose of the research was to analyze imagery and attention capacities in badminton players. 85 players aged 16-18 who participated in Badminton Turkey Championship in 2016, were involved in this research. Bourdon Attention Test for the attention levels of players participating in the research, Sport Imagery Questionnaire (SIQ) developed by Hall et al. for their imagery capacity were used herein. In evaluation of data, frequency analysis, t-test and correlation analysis were done. In conclusion; any significant differences were not found between imagery capacity and gender variable in badminton players. But a significant difference was found between sport age, cognitive imagery and motivational general competence. When cognitive imagery values increase, motivational general arousal values increase. And when motivational general competence values go up, motivational specific imagery rate rises. In badminton players there was a significant relation between imagery and attention. There was a positive relation between motivational specific imagery and attention. When capacity for motivational specific imagery rises, attention capacity rises in players. When players win the match or perform well, they imagine to be appreciated (Motivational Specific Imagery), this positively affects attention capacity. Imagery trials accompanied by physical trainings are influential for improving players' attention capacity.
\end{abstract}

Keywords: Attention, badminton, imagery.

\section{INTRODUCTION}

Imagery is a capability to create an opinion or a picture in mind (17), imagine or revive an experience in mind (37). Imagery seems to be an important and effective practice for sportive performance $(23,36)$. Sport skills are imagined in three ways. An athlete feels like in its own body and works in such a way (intrinsic imagery), an athlete considers oneself as a film player when performing any skill (extrinsic imagery) and an athlete can exercise by imagining another person who performs an ideal skill (7). In particular, strategies such as selfconfidence, relaxation, motivation, target determination and concentration practices in accordance with an athlete's individual differences and needs can be applied (3). Within a study focused on exercise and imagery, imagery was related with individuals' motivation, intention for exercise and exercise behaviour (32). Researches showed that athletes used four types of imagery (visual, kinesthetic, audial and olfactory), the mostly used ones were known to be visual and kinesthetic imagery (37). Attention is the most essential key element to control opinion processes, concentrate on a duty and show an effective performance in sport
(26). Attention is a basic component of human data processing system. Since human beings cannot process all relevant information at once, human capacity is described to be a limited system. Attention is necessary for providing information to a processor in this limited capacity (14). Many researches were done on attention, concentration, hand-eye coordination and reaction time concepts, and activities in a certain period of time were determined to affect these items $(4,8)$. Reaction time is an important factor for badminton sport whichin shuttlecock speed is $320 \mathrm{~km} /$ hour in elite athletes on average (24). Like in other sports with racket, there are short-term maximal or submaximal overloads and short-term rest periods in badminton. In these types of sport branches, especially high aerobic capacity is required to move continuously and rapidly (15) as well as speed, endurance, strength, coordination, reaction, anticipation, game skills and techniques (5). Badminton is a sportive game which is mutually played by two persons or two by two persons, requires to throw a ball made of goose feather or plastics with a light racket kept in only one hand over a net and drop a ball into the opponent's field, and is based on promptness, 
rapidity, skill, coordination and sudden decisionmaking (13). Badminton is a sport which enables to make decisions rapidly and activates decision mechanism of human brain in seconds in terms of tactics (34). Relation between imagery and attention is considered to concentrate on any work, adjust arousal levels, have an optimum arousal level, focus on clues relating to one's duty and keep irrelevant ones away. So an athlete takes necessary stimulants into consideration owing to imagery for one's success as one keeps stimulants unfavorable for one's performance $(16,31)$. Imagery is defined as a process which prepares a person for performance both physiologically and cognitively (1). In badminton sport branch, it is important for an athlete to keep one's attention level at the maximum level during the game, think the next move in order to complete a move (long step) rapidly, return towards the starting point and move towards different positions. Having good imagery and attention capacities for athletes are considered to be significant factors affecting performance. In the light of these information, the purpose of the research was to analyze imagery and attention capacities in badminton players.

\section{MATERIALS \& METHODS}

Total 85 players including 42 females (50.6\%), 43 males (49.4\%) aged 16-18 who participated in Badminton Turkey Championship in Ankara in 2016, were involved in this research. Bourdon Attention Test for the participant players' attention levels, Sport Imagery Questionnaire (SIQ) developed by Hall et al. (18) for their imagery capacities were used. Sport Imagery Questionnaire (SIQ) : Sport Imagery Questionnaire (SIQ) which was developed for athletes' imagery forms by Hall et al. (Hall et al., 1998), was utilised herein. Sport Imagery Questionnaire was adapted into Turkish by Kızıldağ (21). Sport Imagery Questionnaire consists of 30 items where judgements have seven evaluation steps. Motivation, Self-Respect and Self-Confidence are mentioned in imagery theories, furthermore, the questionnaire has 4 sub-dimensions. These dimensions are Cognitive Imagery, Motivational Specific Imagery, Motivational General Arousal and Motivational General Competence. The Cronbach alpha value of Sport Imagery Questionnaire changes between .68 and .87 . Its sub-dimensions are:

Cognitive Imagery: It is related with carrying performance-based plans out successfully. For instance, they are imagery ones like rehearsing skills peculiar to sport.

Motivational Specific Imagery: This sub-scale involves imagining a thriven performance target. Athletes' images which show their recognition when they win the match or have a good performance, are in this sub-dimension.

Motivational General Arousal: It involves feelings accompanied by significant competitions. This sub-dimension is related with imagining psychological and emotional arousal.

Motivational General Competence: When athletes face technical and tactical problems in competitions, it is one sub-dimension related with how to deal with these ones. It represents an athlete's imagery as self-confident, strong and focused.

Bourdon Attention Test: The final version of Bourdon attention test was developed by Benjamin Bourdon in 1955. There are two different forms of Bourdon attention test. The first one is as finding and marking specific letters among mixed typescripts and the second one is finding and marking specific shapes among mixed shapes given. For the evaluation of the test, the number of true answers, time or number of false answers can be taken into consideration. The operator might evaluate by counting how many true answers the children did in a certain time (9). In this research, Bourdon attention test letter form was used. The participants were desired to find and mark " $b, d, g$ and $\mathrm{p}^{\prime \prime}$ letters. For the assessment of the test, the correct answers given by participants were considered. Each correct answer was accepted as gaining a point. The highest points that might be taken from the test were determined as 118 points. Increasing the point of the person indicated the improvement in his/ her attention level. It is a test which measures attention, tiredness, speed of movement, tempo of work, endurance and working performance in the monotone work process when constant concentration and attention are at a high level (10). In a study performed by Karaduman (20), validation and reliability studies of Bourdon Attention Test were carried out. The correlation coefficient was found as .78.

In the evaluation of data, frequency analysis, $\mathrm{t}$ test and correlation analysis were done. 


\section{RESULTS}

As seen at Table 1, any significant differences were not found between imagery and gender variable in badminton players ( $p>0.05)$. A capacity for imagining a thriven performance target (Motivational Specific Imagery) was higher in female players than male players.

As seen at Table 2, a significant difference was observed between sport age, cognitive imagery and motivational general competence $(p<0.05)$. When cognitive imagery values increase, motivational general arousal values increase. When motivational general competence rate goes up, motivational specific imagery rate increases. When athletes face problems in competition and their self-confident, strong and focused imagery (Motivational General Competence) capacity improves, their target imagery and their appreciation imagery due to winning the match (Motivational Specific Imagery) positively increase.

As seen at Table 3, a significant difference was found between imagery and attention in badminton players $(p<0.05)$. There was a positive relation between motivational specific imagery and attention. When motivational specific imagery capacity increases in athletes, attention capacity increases. When athletes win the match or show a good performance, they imagine to be appreciated (Motivational Specific Imagery), this positively affects attention capacity.

\section{DISCUSSION}

In this study aimed at analyzing imagery and attention capacities in badminton players, there were not any significant differences between imagery and gender variable in badminton players but female players' capacity for imagining a thriven performance target (Motivational Specific Imagery) was higher than male players (Table 1). In a study titled with An Investigation of Imagery, Intrinsic Motivation, Self-Efficacy and Performance in Athletes, there was not any meaningful relation between gender and imagery skill (30).

Table 1. Analysis of imagery capacities in badminton players in accordance with gender variable.

\begin{tabular}{llllccc}
\hline & Gender & $\mathrm{N}$ & Mean & $\mathrm{SD}$ & $\mathrm{t}$ & $\mathrm{p}$ \\
\hline Cognitive Imagery & Male & 42 & 45.21 & 10.51 & -.267 & .790 \\
& Female & 43 & 45.74 & 7.60 & & \\
Motivational Specific Imagery & Male & 42 & 25.66 & 6.11 & -.991 & .324 \\
& Female & 43 & 27.00 & 6.27 & & \\
Motivational General Arousal & Male & 42 & 18.19 & 5.56 & -.124 & .902 \\
& Female & 43 & 18.34 & 6.21 & & \\
Motivational General Competence & Male & 42 & 16.02 & 3.91 & -.455 & .650 \\
& Female & 43 & 16.41 & 4.07 & & \\
\hline
\end{tabular}

Table 2. Analysis of imagery capacities in badminton players in accordance with sport age variable.

\begin{tabular}{lccccc}
\hline & & Sport Age & $\begin{array}{c}\text { Cognitive } \\
\text { Imagery }\end{array}$ & $\begin{array}{c}\text { Motivational } \\
\text { Specific Imagery }\end{array}$ & $\begin{array}{c}\text { Motivational } \\
\text { General Arousal }\end{array}$ \\
\hline Cognitive Imagery & $\mathrm{r}$ & $.290^{*}$ & & & \\
& $\mathrm{p}$ & .007 & & & \\
Motivational Specific Imagery & $\mathrm{N}$ & 85 & 85 & & \\
& $\mathrm{r}$ & .165 & $.600^{*}$ & & \\
& $\mathrm{p}$ & .132 & .000 & & \\
Motivational General Arousal & $\mathrm{N}$ & 85 & 85 & 85 & \\
& $\mathrm{r}$ & .075 & $.311^{*}$ & .184 & \\
& $\mathrm{p}$ & .494 & .004 & .092 & 85 \\
Motivational General Competence & $\mathrm{N}$ & 85 & 85 & 85 & .172 \\
& $\mathrm{r}$ & $.327^{*}$ & $.662 *$ & $.744^{*}$ & .115 \\
& $\mathrm{p}$ & .002 & .000 & .000 & 85 \\
\hline
\end{tabular}

${ }^{*}$ Correlation is significant at the 0.01 level (2-tailed). 
Table 3. Analysis of imagery and attention relation in badminton players.

\begin{tabular}{lccccc}
\hline & & $\begin{array}{c}\text { Cognitive } \\
\text { Imagery }\end{array}$ & $\begin{array}{c}\text { Motivational } \\
\text { Specific Imagery }\end{array}$ & $\begin{array}{c}\text { Motivational } \\
\text { General Arousal }\end{array}$ & $\begin{array}{c}\text { Motivational General } \\
\text { Competence }\end{array}$ \\
\hline Motivational Specific Imagery & $\mathrm{r}$ & $.600^{* *}$ & & \\
& $\mathrm{p}$ & .000 & & \\
Motivational General Arousal & $\mathrm{N}$ & 85 & 85 & \\
& $\mathrm{r}$ & $.311^{* *}$ & .184 & & \\
& $\mathrm{p}$ & .004 & .092 & 85 \\
Motivational General Competence & $\mathrm{r}$ & $.662^{* *}$ & $.744^{* *}$ & .172 & .115 \\
& $\mathrm{p}$ & .000 & .000 & 85 &. .126 \\
Attention Value & $\mathrm{N}$ & 85 & 85 & .251 & $.257^{*}$ \\
& $\mathrm{r}$ & .136 & $.226^{*}$ & .017 \\
\end{tabular}

* Correlation is significant at the 0.05 level (2-tailed). ${ }^{* *}$ Correlation is significant at the 0.01 level (2-tailed).

In badminton players there was a meaningful relation between sport age variable, cognitive imagery and motivational general competence. When cognitive imagery values increase, motivational general arousal values increase. When motivational general competence rate rises, motivational specific imagery rate increases as well. When athletes face problems in competitions and their capacity for self-confidence, strength and focus-based imagery (Motivational general competence) increases, their capacity for imagining target and recognition with winning the match (Motivational Specific Imagery) increases in a positive way (Table 2). A research studied the relation between athletes' imagery, motivation and anxiety points and revealed that there was a positive relation between cognitive imagery, motivational general competence and sport age (22).

Another research studied the effects of imagery trials on problem-solving skills to develop elite athletes' success and revealed that programs for imagery trials had positive effects on footballers' problem-solving skills (2). Callow and Hardy (12) researched on badminton players and suggested that imagery developed players' confidence. Munroe-Chandler et al. (25) reported that imagery efforts caused a high performance in some football skills (such as pass, pace, shot) of athletes aged 7-14.

In badminton players there was a meaningful relation between imagery and attention. There was a positive relation between motivational specific imagery and attention. When capacity for motivational specific imagery in athletes increases, their attention capacity develops. When athletes win the match or have a good performance, they imagine to be appreciated (Motivational Specific Imagery), this affects attention capacity positively (Table 3). Imagery practices reduce tension, anxiety and sympathetic nervous system activation (19). In addition to physical trainings, regular mental trainings are positively effective on developing balance and attention capacities in child footballers (6). Calmels, Berthoumieux and d'ArripeLongueville's study (11) indicated that there was an increase in focused attention of professional athletes having imagery education. Some researches showed that mental trainings increased performance in duties associated with motor skills $(25,35,27,29)$. A study on the effect of imagery types on sportive performance concluded that athletes who imagined, had the best performance increase rather than other athletes (33). Among tennis players, service skills developed more in persons with higher imagery capacity rather than persons with lower ones (28). These studies are in parallel with our findings.

In conclusion, there was not any significant difference between imagery and gender variable in players but a capacity for imagining a thriven performance target (Motivational Specific Imagery) was higher in female athletes. There was a significant relation between sport age variable, cognitive imagery and motivational general competence. When athletes are confronted with problems in competitions and their capacity for self- 
confident, strong and focused imagery (Motivational General Competence) increases, their target imagery and their appreciation imagery with the reason of winning the match (Motivational Specific Imagery) positively increases. A meaningful relation was seen between imagery and attention capacity. Furthermore, a positive relation was seen between motivational specific imagery and attention. When athletes win the match or have a good performance, they imagine to be appreciated (Motivational Specific Imagery), this leads to a positive increase in attention capacity. In order to show a good performance for athletes, it is suggested to do physical trainings accompanied by mental trainings, to improve mental processes such aas imagery and attention.

\section{REFERENCES}

1. Abdin, Junayd M. Imagery for sport performance: A comprehensive literature review. Yayınlanmamış Master Tezi. Muncie, Indiana: Ball State University Applied Sciences and Technology, 2010.

2. Aldemir YG, Biçer $T$, Kale EK. The effect of imagery interventions on problem solving skill in elite athletes. Journal of Sports and Performance Researches, 2014; 5(2): 3745 .

3. Altıntaş A, Akalan C. Zihinsel antrenman ve yüksek performans. Spormetre Beden Eğitimi ve Spor Bilimleri Dergisi, 2008; 6(1): 39-43.

4. Bańkosz Z, Nawara H, Ociepa M. Assessment of simple reaction time in badminton players. Trends in Sport Sciences, 2013; 20(1): 54- 61.

5. Baron R, Petschnig R, Bachl N, Raberger G, Smekal G, Kastner P. Catecholamine excretion and heart rate as factors of psychophysical stress in table tennis. Int J Sports Med, 1992; 13(7): 501-505.

6. Baştuğ G, Mollaoğulları H, Göral K, Kocacan SA. Investigation of the effect of mental training method on balance and attention of 10-12 years old football players. International Journal of Psychiatry and Psychological Researches, 2015; 4: $167-176$

7. Beşiktaş MY. Spor müsabakalarına psikolojik hazırlıkta imgelemenin rolü ve önemi. Yüksek lisans tezi, Marmara Üniversitesi Sağlık Bilimleri Enstitüsü, İstanbul, 2005.

8. Boot WR, Kramer AF, Simons DJ, Fabiani M, Gratton G. The effects of video game playing on attention, memory, and executive control. Acta Psychologica, 2008; 129: 387-398.

9. Brickenkamp R, Bleck I, Dzida W, Heinrich P, Hellwig HJ, Krüger Naumann R, Rothe R, Speck D, Speck R, Thiede L. Handbuch psychologischer undpaedagogischertests. Göttingen: Verlag für Psychologie, 1975.

10. Brunner YY. Luçse, çem Superาvnimaniye. Rostov-na Donu: Feniks, 2006: 15-16.
11. Calmels, Berthoumieux, d'Arripe-Longueville. Effects of an imagery training program on selective attention of national softball players. Sport Psychologist, 2004; 18(3): 272-296.

12. Callow N, Hardy L. Types of imagery associated with sport confidence in netball players of varying skill levels. Journal of Applied Sport Psychology, 2001: 13(1): 1-17.

13. Demirci A, Demirci N. Adım Adım Badminton. Ankara, 2007.

14. Dewey D, Brawley LR, Allard F. Do the TAIS attentional-style scales predict how visual information is processed? J Sport Exercise Psy, 1989; 11: 171-186.

15. Faude $\mathrm{O}$, Meyer $\mathrm{T}$, Rosenberger $\mathrm{F}$, Fries M, Huber G, Kindermann W. Physiological characteristics of badminton match play. Eur J Appl Physiol, 2007; 100: 479-485.

16. Feltz D, Landers DM. The effects of mental practice on motor skill learning and performance: A meta-analysis. Journal of Sport Psychology, 1989; 5: 25-27.

17. Gawain S. Yaratııı İmgeleme, (çev: Ayanbaşı, S), İstanbul: Akaşa Yayınevi, 2007.

18. Hall CR, Mack D, Paivio A, Hausenblas HA. Imagery use by athletes: Development of the sport imagery questionnaire. Int J Sport Psychol, 1998; 29(1): 73-89.

19. Jing $X$, Wu P, Liu F. Guided imagery, anxiety, heart rate, and heart rate variability during centrifuge training. Aviat Space Env Med, 2011; 82(2): 92-96.

20. Karaduman BD. Effect of Gatherาing Attention Training program on gathering attention level, sense of self and success level of 4 th and 5 th class primary school students. Unpublished PhD Thesis, Ankara University Graduate School of Education Sciences, 2004.

21. Kızıldağ E. Farklı spor branşındaki sporcuların imgeleme biçimleri. Yüksek lisans tezi, Mersin Üniversitesi Sağlık Bilimleri Enstitüsü, Mersin, 2007.

22. Kolayiş H, Sarı İ, Köle Ö. Investigating the relationship among imagery, motivation and anxiety in female athletes from team sports. Ankara Üniversitesi, Spor Bilimleri Fakültesi, 2015; 13(2): 129-136.

23. McIntyre TE, Moran AP. A qualitative investigation of metaimagery processes and imagery direction among elite athletes. J Imagery Res Sport Phys Activ, 2007; 2(1): 1-20 7.

24. Memedov RC, Kale R. Uçan Tüytop Badminton. Başak Ofset, İstanbul, 1994.

25. Munroe-Chandler Krista J. Effects of a cognitive specific imagery intervention on the soccer skill performance of young athletes: Age group comparisons. Psychology of Sport and Exercise, 2012; 13(3): 324-331.

26. Nideffer RM, Segal M. Concentration and attention control training. In J. M. Williams (Ed.), Applied sport psychology: Personal growth to peak performance (4th ed., pp.312-332). Mountain View, CA: Mayfield, 2001.

27. Nordin SM, Cumming J. Types and functions of athletes' imagery: Testing predictions from the applied model of imagery use by examining effectiveness. International Journal of Sport and Exercise Psychology, 2008; 6(2): 189-206.

28. Robin N, Dominique L, Toussaint L, Blandin Y, Guillot A, Le Her M. Effects of motor imagery training on service return accuracy in tennis: The role of image ability. International 
Journal of Sport and Exercise Psychology, 2007; 2: 175-186. 29. Rostami R, Rezaee M. Prediction of cognitive and motivational functions of sports imagery in veteran basketball players. Iranian Journal of War and Public Health, 2014; 6(3): 87-93.

30. Sarı I. An investigation of imagery, intrinsic motivation, selfefficacy and performance in Athletes. Anthropologist, 2015; 20(3): 675-688.

31. Schmidt RA. Motor control and learning: A behavioral emphasis. Champaign, IL: Human Kinetics, 1982.

32. Stanley DM, Cumming J, Standage M. Images of exercising Exploring the links between exercise imagery use, autonomous and controlled motivation to exercise, and exercise intention and behavior. Psychol Sport Exerc, 2012; 13(2): 133-141.
33. Uğur $Y$. The effects of imagery types on sports performance. Abant İzzet Baysal Üniversitesi, Social Sciences Institute, Department of Psychology, Master Thesis, Bolu, 2016.

34. Yumuk S. Badminton. Eskişehir: Lale Matbaası, 2004.

35. Weinberg R, Gould D. Imagery. Foundations of Sport ad Exercise Psychology (4. Baskı) içinde (296-317). Champaign, IL: Human Kinetics, 2007.

36. Weinberg R. Does imagery work? Effects on performance and mental skills. J Imagery Res Sport Phys Activ, 2008; 3(1): 1-21.

37. Weinberg RS, Gould D. Foundations of Sport and Exercise Psychology. (Çeviren: Şahin, M., Koruç, Z.), Nobel Akademik Yayıncılık, 2015: 372. 